\title{
RISALAH|
}

DOI: $10.24014 /$ jdr.v31i1.9527

\section{KREDIBILITAS KOMUNIKATOR JURUS SEHAT RASULULLAH DI KALANGAN FOLLOWERS INSTAGRAM @ZAIDULAKBAR}

\author{
R. Yogie Prawira W. ${ }^{1}$, Hindina Maulida ${ }^{2}$ \\ ${ }^{1,2}$ Universitas Tidar \\ Email: yogieprawira@untidar.ac.id
}

\section{Kata kunci \\ Jurus Sehat \\ Rasulullah, \\ Komunikasi Dakwah, Kredibilitas Sumber}

Keywords

Healthy Style of

Rasullullah, Da'wah

Communication,

Source Credibility

\begin{abstract}
Abstrak
Artikel ini bertujuan untuk mengetahui hubungan kredibilitas komunikator dengan sikap followers akun instagram @zaidulakbar mengenai Jurus Sehat Rasulullah (JSR). Metode penelitian yang digunakan adalah metode kuantitatif studi korelasional dengan tujuan untuk menjelaskan korelasi atau hubungan variabel-variabel dengan menggunakan statistik korelasional. Teknik sampel yang digunakan adalah simple random sampling dengan jumlah sample adalah 100 followers. Teknik pengumpulan data dilakukan dengan menyebarkan kuesioner yang berisi pertanyaan terstruktur dan disebarkan melalui fitur Direct Message (DM) di Instagram. Data yang terkumpul dianalisis dengan teknik analisis deskriptif dan analisis statistik inferensial menggunakan perhitungan statistik Spearman Rank. Hasil penelitian menunjukkan bahwa terdapat hubungan yang tinggi antara kredibilitas komunikator dr. Zaidul Akbar dengan sikap followers akun instagram @zaidulakbar terhadap pola hidup sehat JSR dengan nilai koefisien korelasi mencapai nilai 0,834. Kredibilitas sumber mencakup keahlian, keterpercayaan, dan daya tarik.
\end{abstract}

\begin{abstract}
This study aims to determine the correlation of the source credibility with the attitudes of Instagram account followers@zaidulakbar regarding the healthy style of Rasulullah (JSR). The method used in research is a quantitative method, with correlational studies aimed at expressing relationships between variables through correlational statistics. The sampling technique used was simple random sampling with a total sample of 100 followers. Research data was collected by distributing questionnaires containing structured questions and disseminated via the direct message (DM) feature on Instagram. The data obtained were analyzed using descriptive data analysis techniques and inferential statistical analysis with the Spearman Rank statistical calculation formula (Rs). The results showed that there is a high correlation between the source credibility with the attitude of Instagram account followers @zaidulakbar of 0.834. The source credibility component consists of expertise, trustworthiness, and attractiveness.
\end{abstract}




\section{Pendahuluan}

Setiap muslim mempunyai tanggung jawab berupa kewajiban untuk menyampaikan dakwah sesuai dengan kapasitas dan kemampuannya. Sesuai dengan ajaran Islam yang menjelaskan bahwa dakwah merupakan upaya untuk mengajak manusia ke jalan yang benar dengan cara yang baik dan bijaksana dengan berdasarkan pada perintah Allah guna mencapai kebaikan dan kebahagiaan di dunia dan akhirat (Hasanudin dalam Mulizar, 2017). Dakwah mempunyai dua tingkatan berupa dakwah tekstual dan dakwah kontekstual (Iskan dalam Hidayat, 2013). Dakwah tekstual adalah dakwah yang hanya bersifat penyampaian materi tanpa mempertimbangkan kebutuhan informasi khalayak sehingga tinggi kemungkinan bahwa informasi yang disampaikan sudah sering didengarkan.

Tingkatan dakwah yang kedua, yaitu, dakwah kontekstual merupakan dakwah dengan materi yang dibutuhkan oleh khalayak. Artinya, materi dakwah yang disampaikan bisa membantu memecahkan masalah yang sedang dihadapi oleh masyarakat saat ini secara nyata dan konkrit. Dakwah kontekstual oleh E.Ayub (2007) disebut juga dengan dakwah pembangunan karena bertujuan untuk mewujudkan kesejahteraan masyarakat serta kebahagiaan baik secara rohani maupun jasmani dengan salah satu fokusnya adalah peningkatan kualitas muslim agar menjadi generasi yang mendorong kemajuan. Salah satu bentuk dakwah kontekstual adalah dakwah dalam bidang kesehatan.

Kesehatan merupakan salah satu faktor determinan kehidupan manusia karena kesehatan merupakan dasar untuk meraih kesejahteraan. Agama Islam sangat mengutamakan kesehatan baik lahir maupun batin dan menempatkannya sebagai kenikmatan kedua setelah Iman (Husin, 2014). Banyak anjuran dan ajakan untuk menjaga dan mempertahankan kesehatan yang dimiliki salah satu upayanya adalah dengan mengatur pola hidup sehat. Perilaku pola hidup sehat sangat penting untuk mencegah beberapa kondisi yang kronis (Laranjo, 2016).

Penyakit kronis adalah penyakit yang bertahan lama dengan proses perkembangan yang biasanya cenderung lambat, seperti kanker, diabetes, jantung, hipertensi (darah tinggi) dan stroke (Assupina, 2013). Menurut Rahmadiana (2012) penyebab banyaknya penderita penyakit kronis adalah kurangnya kemauan individu untuk menjalankan hidup sehat, serta kelalaian dan pengingkaran individu terhadap kondisi kesehatan karena terlalu terlena dengan gaya hidup yang kurang sehat.

Konsekuensinya adalah permasalahan kesehatan masih menjadi problematika yang sulit diatasi. Sehingga perlu diberikan informasi kesehatan untuk meningkatkan kesadaran dan pengetahuan, yang pada gilirannya diharapkan dapat mengubah perilaku masyarakat dari tidak sehat menjadi sehat. Undang-Undang Tentang Kesehatan No. 36 Tahun 2009 menyatakan bahwa pembangunan kesehatan membutuhkan sebuah upaya kemasyarakatan melalui edukasi, komunikasi dan informasi. Perkembangan teknologi 
komunikasi dan informasi dengan ragam media yang ada sangat mendukung untuk melakukan upaya tersebut.

Banyaknya informasi kesehatan yang bertebaran bukanlah sebuah hal mengejutkan karena ragam media tersebut semakin memudahkan proses penyampaian informasi kesehatan. Bukan hanya petugas kesehatan saja, tetapi semua orang yang dapat mengakses dan menggunakan perangkat komunikasi dapat melakukannya. Dalam hal ini, dakwah memiliki peluang sekaligus tantangan untuk melakukan dakwah di bidang kesehatan dengan memanfaatkan kemajuan teknologi informasi dan komunikasi yang memiliki daya jangkau yang luas dan masif.

Perkembangan ilmu Teknologi Informasi dan Komunikasi (TIK) yang pesat memudahkan manusia untuk memperoleh informasi dengan cepat, sehingga sudah sepatutnya dakwah juga berkembang dan bervariasi untuk menjangkau lebih banyak manusia (Hidayat, 2013). Dengan kata lain, dakwah seyogyanya juga harus bersifat kontekstual dengan masa sekarang mengingat ajaran Agama Islam bukan hanya sekedar ritual keagamaan tetapi juga masuk ke semua ranah kehidupan yang diimplemestasikan dalam kehidupan nyata. Dengan demikian, bagi orang yang berdakwah diharapkan untuk dapat menyesuaikan perkembangan zaman dan berinovasi dengan menggunakan media-media yang bervariasi dan terbaru dalam aktifitasnya menyampaikan kebenaran ajaran Islam.

Dalam menyampaikan pesan-pesan ajaran Islam, individu dapat melakukannya sesuai dengan keahlian, kemampuan, serta keterampilan yang dimiliki, asalkan tidak bertentangan dengan kaidah dan prinsip ajaran Islam. Hal inilah yang diterapkan dan dilakukan oleh dr. Zaidul Akbar. Seorang dokter yang awalnya memiliki kegelisahan dengan semakin beragamnya penyakit dan meningkatnya jumlah orang yang sakit. Meskipun telah ada obatnya, dokter lulusan Fakultas Kedokteran Universitas Diponegoro tersebut mengaku ragu dengan kehalalan obat. Kekhawatiran yang dimilikinya, menjadikan dia banyak belajar, berdiskusi, dan mengkaji tentang kesehatan dan pengobatan herbal, bekam dan thibbun nabawi.

Dokter Zaidul Akbar menjelaskan bahwa Islam merupakan agama yang sempurna dengan tuntunan hidup yang menyehatkan mulai dari bangun hingga tidur lagi sebagaimana dicontohkan oleh Nabi Muhammad SAW. Fakta inilah yang mendorong dr. Zaidul Akbar untuk menjadi pendakwah dibidang kesehatan, karena menurutnya kesehatan itu murah dan biayanya rendah serta bisa diraih oleh siapapun. Sebagaimana yang ditulis oleh Hidayat (2013) tentang dakwah kontekstual, bahwa ahli dari berbagai ilmu harus fokus untuk merancang langkah konkrit dalam menyelesaikan permasalahan manusia.

Pola hidup sehat yang dipopulerkan oleh dr. Zaidul Akbar adalah Jurus Sehat Rasulullah atau yang lebih dikenal dengan JSR. JSR (Jurus Sehat Rasulullah) merupakan gaya hidup sehat dengan konsep utama berupa usaha mengurangi makanan dengan bahan dasar tepung, meningkatkan jumlah konsumsi buah dan sayur, serta 
memperbanyak konsumsi rimpang, seperti jahe dan kunyit. Media penyebaran yang digunakan adalah media sosial yang banyak digunakan dan diakses oleh masyarakat saat ini, seperti instagram, youtube, dan juga telegram. Dalam dakwah kesehatannya, dr. Zaidul Akbar secara aktif dan konsisten membagikan informasi baik resep, takaran maupun kegunaannya.

Keaktifannnya menyampaikan informasi, menurut Hidayat (2013) adalah langkah yang tepat karena dakwah harus bersifat aktif dan bukan pasif atau menunggu mengingat dakwah merupakan kegiatan persuasif yang berupaya untuk membujuk orang lain agar dengan sukarela mengikuti pesan dakwahnya. Oleh karenanya sang penyampai informasi (da'i) harus memulai terlebih dahulu serta mampu memberikan umpan balik kepada khalayak (reaktif). BS. Ma'arif dkk (2019) menegaskan bahwa kegiatan dakwah biasanya tergantung pada da'i atau komunikatornya.

Komunikator adalah orang yang menyampaikan pesan sehingga dapat dimengerti dan diterima oleh khalayak (Prasetyo, 2019). Untuk dapat membuat khalayak memahami dan menerima sebuah pesan maka komunikasi harus berjalan secara efektif. Berhasil atau tidaknya sebuah komunikasi efektif tergantung dari cara komunikator untuk dalam mempengaruhi khalayak. Tujuannya adalah khalayak dapat bertindak seperti yang diinginkan oleh komunikator, atau bahkan terjadi perubahan sikap dan perilaku.

Dalam komunikasi dakwah, seorang da'i yang merupakan komunikator tidak hanya memiliki fungsi tunggal sebagai penyampai informasi tetapi juga sebagai contoh teladan dan pendorong dalam kehidupan sehari-hari. Oleh karenanya, komunikator dalam komunikasi dakwah harus orang yang memiliki pengetahuan dan keahlian. Sebagaimana penelitian yang dilakukan oleh Homer and Kahle bahwa pemilihan komunikator dan keahlian komunikator berpengaruh terhadap keterlibatan khalayak. Hal ini mengingat khalayak akan memperhatikan siapa yang berkata, dan bukan apa yang dikatakan (Riswandi, 2013).

Konsep tersebut sesuai dengan teori kredibilitas sumber yang dikembangkan dalam penelitian Hovland, Janis dan Kelley pada tahun 1953. Teori kredibilitas sumber menjelaskan bahwa seseorang akan lebih mudah memproses informasi dan membentuk sebuah sikap apabila sumber memiliki keahlian, keterpercayaan, daya tarik dan kekuatan (Lamm, Alexa J. et.al, 2016; Rakhmat, 2019). Dengan kata lain, khalayak akan lebih mudah untuk terbujuk dan mengikuti perkataan komunikator, apabila komunikator memiliki kredibilitas yang cukup tinggi.

Sebagaimana hasil penelitian tentang kredibilitas komunikator yang menunjukkan bahwa, informasi yang disampaikan oleh orang yang terkenal, dan dianggap ahli memiliki pengaruh yang lebih kuat dibandingkan dengan orang yang kurang kredibilitasnya (Telg, Ricky et. al, 2012). Hal ini juga berlaku dalam komunikasi dakwah, seperti penelitian (Sundary \& Fahmi, 2018) yang mengkaji tentang hubungan antara kredibilitas, daya tarik, dan kekuasaan komunikasi dakwah dengan pengetahuan 
keagamaan. Hasil penelitian menemukan bahwa terdapat hubungan yang cukup signifikan antara kredibilitas komunikator dengan pengetahuan yang dimiliki oleh jemaah.

Hasil temuan tersebut senada dengan penelitian kredibilitas komunikator (Rahmah, 2013; Alsakinah, 2018; Hariyanto, 2018; Ashfiah, 2019) yang mengemukakan bahwa dalam komunikasi dakwah, kredibilitas komunikator penting dan cukup berpengaruh terhadap kemauan jama'ah (khalayak) untuk bergabung dalam kegiatan dakwah atau mendengarkan, dan menerima pesan yang disampaikan oleh komunikator. Hal lain yang juga ditemukan adalah kredibilitas komunikator dakwah bersifat relatif dan tidak semua komunikator memenuhi semua aspek dalam teori kredibilitas sumber (Rahmah, 2013; Hariyanto, 2018).

Merujuk pada pemaparan sebelumnya, penelitian ini penting untuk dilakukan dengan beberapa alasan. Pertama, belum ada penelitian yang membahas tentang dr. Zaidul Akbar maupun pola hidup sehat JSR. Kedua, mayoritas penelitian sebelumnya meneliti tentang kredibilitas komunikator dakwah tekstual, sedangkan penelitian ini akan mengkaji kredibilitas komunikator dakwah kontekstual di bidang kesehatan yang dilakukan oleh dr. Zaidul Akbar. Dr. Zaidul Akbar dapat dikatakan sebagai pelopor dakwah kesehatan di Indonesia dengan followers yang banyak dalam jangka waktu yang tidak lama. Ketiga, pola hidup sehat JSR yang digagas oleh dr. Zaidul Akbar sangat fenomenal dan viral karena banyak diperbincangkan di media sosial. Masyarakat mengakui bahwa mereka ingin mengetahui serta menerapkannya dalam kehidupan sehari-hari baik untuk mengobati penyakit, untuk gaya hidup sehat atau untuk mengikuti sunnah.

Keempat, dr. Zaidul Akbar memiliki followers yang lebih dari 2 juta akun, dimana followers tersebut terus bertambah setiap hari. Banyaknya followers yang mengikuti akun instagram (IG) dr. Zaidul. Akbar menunjukkan bahwa komunikasi dakwah kesehatan ini menarik perhatian dan diikuti banyak orang. Hal ini terlihat dari testimoni yang diberikan oleh followersnya tentang keberhasilan dan konsistensi dalam menjalankan pola hidup sehat JSR. Followers tersebut, seringkali juga menjadi penyambung lidah JSR di media sosialnya sehingga banyak akun-akun yang secara tidak resmi menggaungkan gerakan hidup sehat 'JSR.

Selain hangat diperbincangkan di media sosial, kajian dan seminar JSR banyak pula diadakan oleh lembaga dakwah maupun non dakwah dengan mengundang langsung penggagasnya sebagai pembicara. Fakta tersebut menunjukkan bahwa dr. Zaidul Akbar memiliki daya persuasif yang kuat sehingga mampu mengajak masyarakat untuk memiliki hidup yang lebih sehat. Berdasarkan pemaparan urgensi tersebut, penelitian ini bertujuan untuk mengetahui hubungan kredibilitas komunikator dengan sikap followers akun instagram @zaidulakbar mengenai pola hidup sehat JSR. 


\section{Metode}

Penelitian ini menggunakan metode kuantitatif, yaitu penelitian ilmiah sistematis mengenai bagian-bagian dan fenomena-fenomena serta hubungan-hubungannya, yang bertujuan untuk menggunakan dan mengembangkan model matematis, teori, dan hipotesis yang berhubungan dengan fenomena alam. Studi yang digunakan adalah studi korelasional dengan tujuan untuk menjelaskan korelasi atau hubungan variabel-variabel dengan menggunakan statistik korelasional (Rakhmat \& Ibrahim, 2017).

Menurut (Rakhmat \& Ibrahim, 2017) salah satu penggunaan desain penelitian korelasional adalah untuk mengukur hubungan diantara berbagai variabel. Dalam penelitian ini terdapat dua variabel yang akan diukur, yaitu variabel X dan Y. Variabel $\mathrm{X}$ dalam penelitian ini adalah kredibilitas komunikator dr. Zaidul Akbar yang diartikan sebagai seperangkat persepsi followers akun Instagram @zaidulakbar tentang sifat dr. Zaidul Akbar. Persepsi tersebut meliputi expertise, trustworthiness dan attractiveness. Variabel yang pertama Expertise sebagai $\mathrm{X}_{1}$, yakni sekumpulan keahlian dr. Zaidul Akbar yang meliputi pengetahuan, keterampilan, kualifikasi dan pengalaman; Trustworthiness sebagai $\mathrm{X}_{2}$ merupakan keterpercayaan khalayak terhadap dr. Zaidul Akbar yang meliputi objektif, kejujuran, integritas dan rasa tanggung jawab sosial; Attractiveness sebagai $\mathrm{X}_{3}$ merupakan daya tarik fisik dan daya tarik psikologis dr. Zaidul Akbar. Daya tarik fisik meliputi tubuh dan gaya berpakaian. Daya tarik psikologis diukur melalui kesamaan agama, kesamaan ideologi, keakraban, kesukaan pada figur dan kesukaan pada pekerjaan (Ohanian, 1991; Prawira W et al., 2012; Rakhmat, 2019).

Sedangkan yang menjadi variabel Y adalah sikap followers akun instagram @ zaidulakbar terhadap JSR yang diukur melalui beberapa aspek, yakni: (1) Aspek kognitif, pengetahuan yang dimiliki followers akun instagram@zaidulakbar terhadap JSR. Aspek ini meliputi pemahaman tentang JSR, informasi tentang JSR dan khasiat dari JSR; (2) Aspek afektif, yaitu perasaan yang dimiliki followers akun instagram @ zaidulakbar terhadap JSR. Aspek ini meliputi penerimaan, penilaian, dan rasa suka terhadap JSR; (3) Aspek konatif, yang merupakan kecenderungan followers akun instagram@zaidulakbar untuk melaksanakan JSR.

Populasi dalam penelitian adalah followers akun instagram @zaidulakbar yang berjumlah 2 juta followers. Sugiyono (2010) mengatakan populasi adalah "wilayah generalisasi yang terdiri atas objek atau subjek yang mempunyai kualitas dan karakteristik tertentu yang ditetapkan oleh peneliti untuk dipelajari dan kemudian ditarik suatu kesimpulan". Selanjutnya sampel akan ditarik dengan menggunakan teknik simple random sampling dan dalam penentuan jumlah ukuran sampel maka digunakan rumus Slovin (Kriyantono, 2012). Berdasarkan rumus tersebut, maka jumlah sampel dalam penelitian adalah sebesar 100 followers, berikut rincian perhitungannya: 


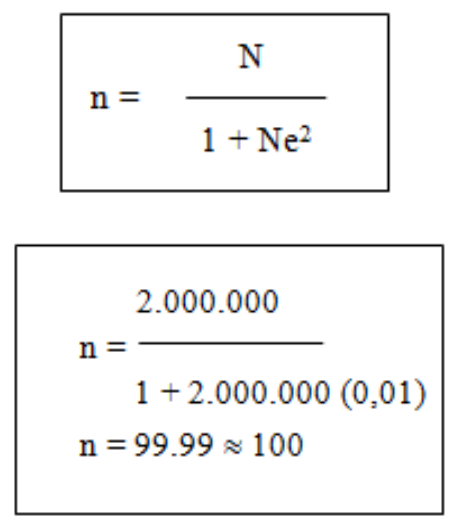

\section{Keterangan:}

$\mathrm{n}=$ ukuran sampel

$\mathrm{N}=$ ukuran populasi

e $=$ kelonggaran ketidaktelitian karena kesalahan pengambilan sampel 10\%

Data penelitian dikumpulkan dengan cara menyebarkan angket yang berisi pernyataan terstruktur, yakni daftar pernyataan dan jawaban sudah tersedia sehingga responden dapat langsung memilih jawaban yang paling sesuai. Dalam penelitian ini, angket disebarkan ke sample penelitian yang berjumlah 100 orang secara random melalui fitur direct message (DM) di instagram. Selain menyebarkan angket, data juga dikumpulkan melalui wawancara, observasi akun instagram responden, dan studi kepustakaan yang terkait.

Data yang terkumpul kemudian dianalisa menggunakan analisis deskriptif. Analisis deskriptif dilakukan untuk dapat menyajikan gambaran mengenai objek penelitian dengan merujuk pada data dan variabel yang diperoleh dari kelompok subjek yang diteliti (Azwar, 2010). Langkah tersebut, namun demikian, bukan untuk melakukan uji hipotesis. Tahapan pertama dalam analisis deskriptif adalah dengan mendeskripsikan jawaban responden dari kuesioner dalam bentuk tabel. Selanjutnya, tabel yang berisi data yang telah diklasifikasikan dan ditabulasikan diubah dalam bentuk distribusi frekuensi dan presentase yang selanjutnya dianalisis berlandaskan teori dan dukungan data lain berupa wawancara, observasi, dan studi literatur.

Penelitian ini juga menggunakan analisis statistik inferensial guna memahami keberadaan hubungan antar variabel dan juga untuk menggambarkan kesimpulan yang sama pada populasi yang lebih besar dari data yang terkumpul. Rumus penghitungan statistik yang digunakan adalah rank spearman, yaitu koefisien korelasi yang menunjukkan memperlihatkan korelasi antara dua variabel $\mathrm{X}$ dan $\mathrm{Y}$ yang keduanya memiliki pengukuran sekurang-kurangnya ordinal. Berdasarkan uraian tersebut, maka hipotesis yang diuji dalam penelitian ini adalah: (1) $\mathrm{H}_{0}$ : Tidak ada hubungan antara kredibilitas komunikator dr. Zaidul Akbar dengan sikap followers instagram @ zaidulakbar terhadap pola hidup sehat JSR; (2) $\mathrm{H}_{1}$ : Ada hubungan antara kredibilitas komunikator dr. Zaidul Akbar dengan sikap followers instagram @zaidulakbar terhadap pola hidup sehat JSR. 


\section{Hasil dan Pembahasan}

Berdasarkan hasil kuesioner yang telah disebar ke responden secara acak melalui fitur Direct Message (DM) di Instagram, diperoleh data karakteristik responden sebagai berikut:

Tabel 1. Karakteristik Responden

\begin{tabular}{llcc}
\hline \multicolumn{1}{c}{ Kategori } & Jawaban & f & Persentase \\
\hline Jenis kelamin & Pria & 28 & $28 \%$ \\
\multirow{3}{*}{ Generasi } & Wanita & 72 & $72 \%$ \\
\multirow{5}{*}{ Pendidikan terakhir } & Xennials & 56 & $56 \%$ \\
& Millenial awal & 44 & $44 \%$ \\
\multirow{5}{*}{ Konsistensi menerapkan JSR } & SMA & 10 & $10 \%$ \\
& Sarjana & 69 & $69 \%$ \\
& Pascasarjana & 21 & $21 \%$ \\
& Sudah & 70 & $70 \%$ \\
\hline
\end{tabular}

Sumber: Hasil Olahan Data Penelitian, 2019

Hasil olah data penelitian mengenai profil responden diketahui bahwa followers akun instagram@zaidulakbar sebagian besar adalah perempuan sebanyak 72 orang atau $72 \%$ dari sampel penelitian. Adapun followers yang berjenis kelamin laki-laki, yaitu sebanyak 28 atau 28\%. Data tersebut menunjukkan bahwa sample penelitian mayoritas adalah perempuan. Sebagaimana hasil penelitian (Yasin \& Ozen, 2011; Andreassen et.al, 2007; Ybarra \& Suman, 2006) yang menunjukkan bahwa perilaku pencarian informasi kesehatan didominasi oleh perempuan dibandingkan laki-laki dengan menggunakan media internet. Alasannya adalah peran wanita sebagai penjaga keluarga menjadikan perempuan lebih agresif dalam mencari informasi kesehatan $e$-health baik untuk dirinya sendiri maupun untuk keluarganya.

Responden dalam penelitian dikategorikan berdasarkan generasi. Berdasarkan tabel karakteristik responden, diketahui bahwa sebagian besar responden yang merupakan followers akun instagram @zaidulakbar adalah xennials sebanyak 56\% responden atau 56 orang. Sedangkan sisanya adalah millenials awal, yaitu generasi yang lahir pada kisaran tahun 1984-1990. Xennials merupakan generasi yang lahir antara tahun 1978-1983 (Cass, 2013). Menurut Cass (2013) xennials lebih menyukai produk yang alami atau natural dibandingkan millenials. Dengan demikian, dominasi Xennials sebagai responden penelitian bukanlah sebuah hal yang mengejutkan mengingat akun instagram@zaidulakbar menawarkan pola hidup sehat JSR dengan bahan herbal. Data pendidikan terakhir dari hasil olah angket penelitian menunjukkan bahwa mayoritas responden berpendidikan sarjana sebanyak $69 \%$ atau 69 orang, pascasarjana $21 \%$ atau 21 orang, dan sisanya sebanyak $10 \%$ atau 10 orang adalah lulusan sekolah menengah atas (SMA). Data tersebut menunjukkan bahwa pendidikan tinggi mempengaruhi kesadaran dan perilaku individu untuk mencari dan menjalankan pola hidup sehat. 
Notoatmojo (dalam Wawan \& Dewi, 2010) menyatakan bahwa perilaku individu dipengaruhi oleh tingkat pendidikan yang dimiliki karena perilaku merupakan wujud nyata dari pengetahuan yang diperoleh. Dengan demikian semakin tinggi pendidikan seseorang, maka semakin tinggi pula kemampuan untuk memahami, menerima dan menyerap informasi kesehatan yang ada (Mubarak, 2011 dan Ilham et al., 2019).

Berdasarkan tabel olah data penelitian tentang konsistensi penerapan pola hidup sehat JSR, ditemukan bahwa responden selaku followers akun instagram @zaidulakbar sebagian besar sudah konsisten menerapkan pola hidup sehat JSR. Jumlah responden yang konsisten adalah 70 orang dengan persentase $70 \%$ sedangkan yang belum konsisten berjumlah 30 orang dengan persentase 30\%. Responden yang konsisten menyatakan bahwa mereka mendapatkan manfaat dari pola hidup sehat JSR sebagaimana testimoni yang dibagikan di instagram. Manfaat yang dirasakan oleh responden sesuai dengan hasil penelitian (Rooney et al., 2013; Conner et al., 2017; Wahl et al., 2017) yang menyatakan bahwa mengkonsumsi buah-buahan dan sayursayuran memberikan manfaat kesehatan fisik dan mental dan bahkan investasi kesehatan di masa mendatang.

Untuk mengetahui hubungan antara kredibilitas dr. Zaidul Akbar dengan sikap followers akun instagram @zaidulakbar terhadap pola hidup sehat JSR maka peneliti menggunakan analisis data dengan koefisien korelasi rank spearman (rs). Hasil perhitungan dapat dilihat pada tabel di bawah ini.

Tabel 2. Rekapitulasi Korelasi Variabel Uji

\begin{tabular}{|c|c|c|c|}
\hline Variabel & rs & Keputusan & Hasil Uji \\
\hline Expertise $\left(\mathrm{X}_{1}\right)$ dengan sikap followers $(\mathrm{Y})$ & 0,750 & $\mathrm{H}_{0}$ ditolak & $\begin{array}{l}\text { Hubungan yang } \\
\text { tinggi; kuat }\end{array}$ \\
\hline $\begin{array}{l}\text { Trustworthiness }\left(\mathrm{X}_{2}\right) \text { dengan sikap followers } \\
\text { (Y) }\end{array}$ & 0,706 & $\mathrm{H}_{0}$ ditolak & $\begin{array}{l}\text { Hubungan yang } \\
\text { tinggi; kuat }\end{array}$ \\
\hline $\begin{array}{l}\text { Attractiveness }\left(\mathrm{X}_{3}\right) \text { dengan sikap followers } \\
(\mathrm{Y})\end{array}$ & 0,771 & $\mathrm{H}_{0}$ ditolak & $\begin{array}{l}\text { Hubungan yang } \\
\text { tinggi; kuat }\end{array}$ \\
\hline $\begin{array}{l}\text { Kredibilitas komunikator (X) dengan sikap } \\
\text { followers (Y) }\end{array}$ & 0,834 & $\mathrm{H}_{0}$ ditolak & $\begin{array}{l}\text { Hubungan yang } \\
\text { tinggi; kuat }\end{array}$ \\
\hline
\end{tabular}

Sumber: Hasil Olahan Data Penelitian, 2019

Berdasarkan tabel di atas, diketahui bahwa terdapat hubungan yang tinggi antara expertise dr. Zaidul Akbar dengan sikap followers akun instagram @zaidulakbar terhadap pola hidup sehat JSR yang terlihat dari nilai koefisien korelasi mencapai nilai 0,750. Expertise (keahlian) merupakan sekumpulan keahlian dr. Zaidul Akbar yang meliputi pengetahuan, keterampilan, kualifikasi dan pengalaman.

Menurut Davenport \& Prusak (2000) pengetahuan adalah kumpulan dari pengalaman, nilai-nilai, informasi kontekstual, dan sudut pandang keahlian individu yang menyajikan garis kerja guna menilai dan mengumpulkan pengalaman dan 
informasi baru dimana keduanya berawal dan diaplikasikan dalam pemikirannya. Terdapat dua kategori pengetahuan, yaitu pengetahuan deklaratif berupa pengetahuan yang berkaitan dengan informasi faktual dan pengetahuan prosedural sebagai tipe pengetahuan yang fokus pada bagaimana proses dibalik sebuah tindakan (Pangil \& Nasurddin, 2013).

Dr. Zaidul Akbar sebagai komunikator memiliki banyak pengetahuan tentang kesehatan dan pola hidup sehat JSR. Pengetahuan tidak hanya dalam tataran teoretis dan konseptual namun juga dalam penerapannya dalam kehidupan sehari-hari. Hal ini terlihat dari postingan instagramnya yang menjabarkan manfaat JSR dengan fakta-fakta yang merujuk pada penelitian ilmiah. Dr. Zaidul Akbar juga menguraikan bagaimana pola hidup sehat yang digagasnya memberikan dampak kesehatan baik jangka pendek maupun jangka panjang.

Memiliki pengetahuan yang komprehensif merupakan sebuah keharusan bagi seorang komunikator dakwah, sebagaimana yang diungkapkan oleh Rahmah (2013) bahwa juru dakwah harus memiliki ilmu pengetahuan dan pemahaman yang mendalam. Disamping itu, juru dakwah atau komunikator juga harus mempunyai keterampilan dan kepandaian dalam menyampaikan dakwahnya. Menurut responden, komunikator JSR dapat menyampaikan informasi tentang kesehatan dan pola hidup sehat yang digagasnya dengan jelas dan mudah dipahami.

Hal tersebut disebabkan oleh kualifikasi pendidikan yang dimiliki oleh dr. Zaidul Akbar yang merupakan lulusan S1 Ilmu Kedokteran. Kualifikasi pendidikan yang dimilikinya menjadikan komunikator memiliki banyak pengalaman dalam bidang kesehatan. Menurut Braunsberger \& Munch (1998) pengalaman merupakan representasi dari tingkat keakraban yang relatif tinggi oleh komunikator dengan bidang subjek tertentu yang diperoleh melalui beberapa jenis paparan.

Dalam konteks kesehatan dan pola hidup sehat JSR, dr. Zaidul Akbar dianggap telah berpengalaman tidak hanya sebagai dokter secara umum tetapi juga dokter yang telah menggunakan dan mengajarkan produk JSR. Oleh karenanya banyak followers yang terpersuasi untuk memiliki sikap positif terhadap pola hidup sehat tersebut. Fakta tersebut senada dengan hasil penelitian yang menyebutkan bahwa komunikator yang memiliki pengalaman yang lebih banyak lebih meyakinkan dibandingkan dengan komunikator yang memiliki sedikit pengalaman (Schindler et al., 2017).

Terkait upaya mempersuasi khalayak, komunikator tidak hanya harus memiliki pengalaman, tetapi juga kualifikasi pendidikan, pengetahuan, dan keterampilan sebagai dimensi keahlian komunikator. Keahlian komunikator adalah kesan atau penilaian yang dibentuk oleh khalayak tentang kemampuan komunikator dalam hubungannya dengan topik yang dibicarakan (Rakhmat, 2019). Keahlian komunikator tidak selalu melekat dalam dirinya melainkan dapat dibentuk atau diupayakan dengan cara memenuhi dimensi-dimensi tersebut. 
McGuire (dalam Braunsberger \& Munch, 1998) menyampaikan bahwa keahlian komunikator merupakan dimensi yang paling penting dalam kredibilitas komunikator. Menurutnya, beberapa kajian menemukan bahwa dimensi kredibilitas komunikator berkaitan positif dengan keberhasilan upaya persuasi terhadap khalayak. Keahlian komunikator memiliki peran yang signifikan, karena terdapat harapan dari khalayak bahwa informasi yang diberikan adalah valid atau akurat, terlebih jika dikaitkan dengan informasi yang berasal dari sosial media (Westerman et al., 2014). Berkaitan dengan hal tersebut Hovland, Janis, \& Kelley, 1953; Hovland \& Weiss, 1951; Kelman \& Hovland, 1953 (dalam Clark et al., 2012) menguraikan bahwa penerima pesan akan lebih termotivasi untuk memperhatikan informasi secara seksama dan lebih mudah dipersuasi oleh komunikator yang ahli daripada komunikator yang kurang ahli. dr. Zaidul Akbar sebagai komunikator dakwah kesehatan, menurut responden telah memenuhi aspekaspek keahlian komunikator sehingga dianggap ahli dan dapat merubah sikap responden untuk melaksanakan pola hidup sehat JSR.

Hasil penelitian juga menemukan bahwa terdapat hubungan yang tinggi antara trustworthiness dr. Zaidul Akbar dengan sikap followers akun instagram @zaidulakbar terhadap pola hidup sehat JSR yang terlihat dari nilai koefisien korelasi mencapai nilai 0,706. Trustworthiness merupakan keterpercayaan khalayak terhadap dr. Zaidul Akbar yang meliputi objektif, kejujuran, integritas dan rasa tanggung jawab sosial.

Objektif adalah segala sesuatu yang sesuai dengan kenyataan yang dapat diobservasi, dideskripsikan, dan ditiru (Doyle, 2004). Dimata responden, dr. Zaidul Akbar dianggap mampu menyampaikan informasi secara objektif karena pola hidup sehat JSR dapat diobservasi baik dilihat, didengar, maupun dirasakan. Gaya hidup tersebut juga dapat dideskripsikan dari segi manfaat, bahan, resep, dan aturan pakainya sehingga dapat ditiru oleh responden untuk diterapkan dalam kehidupan sehari-hari. Waters et al., (2014) menuliskan bahwa dalam merespon informasi kesehatan, sebagian besar orang lebih percaya pada sumber yang terpercaya, seperti dokter, daripada sumber yang kurang terpercaya.

Pendapat yang sama juga disampaikan oleh (Fitzgibbon et al., 2014) bahwa mayoritas orang akan memilih untuk mengadopsi perilaku yang lebih sehat, terutama ketika menerima informasi yang akurat dari otoritas yang dipercaya. Keterpercayaan dalam hal ini merupakan tingkatan dimana khalayak mempercayai bahwa komunikator akan menyampaikan kebenaran seperti yang dia ketahui (Westerman et al., 2014). James T. Scarnati (2013) menyebutkan bahwa menceritakan yang sesungguhnya atau dengan kata lain mengkonfirmasi perkataan dengan realitas adalah kejujuran. Dari segi kejujuran, komunikator JSR dipandang jujur dalam memberikan informasi kesehatan baik secara umum maupun yang terkait dengan pola hidup sehat yang digagasnya.

Keterpercayaan juga mengacu pada kemauan komunikator untuk membuat pernyataan yang valid dan tidak bias. Kepentingan pribadi komunikator ditemukan memiliki peranan utama dalam persepsi khalayak terhadap keterpercayaan komunikator 
(Kareklas et al., 2015). Apabila khalayak memandang bahwa motif perkataan atau tindakan komunikator hanya untuk keuntungan dirinya sendiri, maka komunikator menjadi kurang persuasif dibandingkan dengan komunikator yang dianggap tidak mempunyai kepentingan personal (Venus, 2012). Khalayak awam biasanya melihat seseorang sebagai sumber informasi kesehatan dan komunikator yang memiliki kredibilitas tinggi yang memiliki tanggung jawab etis untuk jujur dan menjaga kepercayaan mereka (Parvanta \& Bass, 2020).

Oleh karenanya seorang komunikator selain jujur, juga perlu memiliki integritas yang tinggi untuk mendapatkan dan mempertahankan keterpercayaan dari penerima pesan. Mengingat kejujuran dan integritas adalah dua hal yang penting dalam membangun kepercayaan dan mempertahankan kredibilitas. Integritas adalah mengkonfirmasikan realita dalam perkataan atau menjaga janji (James T. Scarnati, 2013). dr. Zaidul Akbar dianggap memiliki integritas karena mampu menjaga janji bahwa individu yang mau menerapkan JSR sesuai dengan ketentuan, maka akan merasakan manfaat di tubuhnya sebagaimana testimoni yang disampaikan oleh followersnya. Dengan menunjukkan integritas dalam dakwah kesehatan, dr. Zaidul Akbar membangun pondasi untuk membangun lebih banyak keterpercayaan karena persepsi keterpercayaan dapat muncul dalam berbagai bentuk. Persepsi keterpercayaan sering timbul dari konsistensi antara apa yang dikatakan dan apa yang dilakukan, atau dapat juga dengan menghubungkan pengalaman pribadi followers yang sesuai dengan pesan yang disampaikan (Shell \& Moussa, 2007). Konsistensi dr. Zaidul Akbar dalam mengkampanyekan dan melaksanakan JSR merupakan komitmen dan bentuk tanggung jawab sosialnya sebagai seorang dokter.

Tanggung jawab sosial mengacu pada persepsi individual tentang apa yang harus dilakukan untuk membantu masyarakat (Păceşilă, 2018). Sedangkan Anderson and Cunningham (dalam Davis et al., 2017) mendefinisikan tanggung jawab sosial sebagai kemauan individu untuk membantu orang lain meskipun tidak mendapatkan imbalan atau keuntungan untuk dirinya sendiri. Sebagaimana yang diakui oleh responden bahwa dr. Zaidul Akbar memiliki kepedulian untuk membantu masyarakat dalam mencegah dan mengobati permasalahan kesehatan dengan berbagi informasi tentang pola hidup sehat JSR.

Komunikator yang peduli dan mau mendengarkan serta berempati terhadap kebutuhan khalayak biasanya lebih persuasif karena khalayak biasanya menilai perilaku, niat dan keterpercayaan dokter dari apa dan bagaimana dokter menyampaikan informasi. Gaya berbicara yang lancar, postur yang santai, dan sikap percaya diri sangat penting untuk meningkatkan respek dan kepercayaan sehingga audiens mau mendengar dan melaksanakan apa yang dikatakan oleh komunikator (Parvanta \& Bass, 2020).

Sebagaimana yang dilakukan oleh responden selaku followers akun instagram @zaidulakbar yang mau mengadopsi perilaku hidup sehat JSR karena keterpercayaan yang dimiliki oleh sang pemilik akun. Hasil penelitian ini semakin meneguhkan bahwa 
keterpercayaan yang tinggi lebih efektif untuk mengajak orang karena audiens menganggap bahwa komunikator adalah orang yang berkarakter, tulus, jujur, sesuai kenyataan dan tidak mementingkan diri sendiri (Silk et al., 2011 dan Lou \& Yuan, 2018).

Hasil olah data penelitian juga menggambarkan bahwa terdapat hubungan yang tinggi antara attractiveness dr. Zaidul Akbar dengan sikap followers akun instagram @ zaidulakbar terhadap pola hidup sehat JSR yang terlihat dari nilai koefisien korelasi mencapai nilai 0,771. Attractiveness merupakan daya tarik fisik dan daya tarik psikologis dr. Zaidul Akbar. Daya tarik fisik meliputi postur tubuh dan gaya berpakaian.

Postur tubuh merupakan salah satu komponen daya tarik fisik individu karena fisik yang menarik merupakan faktor yang signifikan dalam penentuan perubahan opini. Orang yang memiliki fisik menarik dipersepsi masyarakat lebih ramah, lebih lancar bicaranya, lebih terpercaya, lebih meyakinkan, dan lebih baik. Fisik yang menarik dikatakan dapat berkontribusi terhadap efektifitas komunikasi (Gordon et al., 2013). Hasil penelitian Arafat (2018) juga mendukung pernyataan tersebut bahwa citra tubuh ideal berpengaruh terhadap kemampuan interpersonal individu.

Dengan kata lain, individu yang memiliki postur tubuh ideal akan dapat melakukan komunikasi yang lebih efektif terkait kesehatan. Hal ini disebabkan oleh postur tubuh yang ideal merupakan representasi dari fisik yang sehat (Abednego \& Triarini, 2016). Dr. Zaidul Akbar terlihat memiliki postur tubuh yang tegap, bugar dan ideal. Postur tubuh yang dimilikinya menggambarkan bagaimana pola hidup sehat yang dijalankan, sehingga komunikator lebih mudah mempersuasi orang lain untuk mengikuti apa yang dikatakannya tentang pola hidup sehat. Komunikator yang fisiknya menarik dapat mempengaruhi image sebuah produk karena menurut (Gordon et al., 2013) komunikator yang secara konsisten menarik lebih disukai, dipersepsi lebih menyenangkan dan memiliki dampak positif terhadap produk yang terkait dengannya. Persepsi bahwa orang lebih menyukai orang yang memiliki fisik menarik karena selama ini media massa memberikan nilai yang lebih positif kepada orang yang memiliki fisik yang menarik dibandingkan yang tidak menarik.

Parvanta \& Bass (2020) menegaskan bawa untuk mengajak seseorang melakukan apa kita inginkan bukanlah sebuah hal yang mudah. Komunikator harus mampu menjelaskan mengapa mereka harus tertarik untuk mengubah perilaku dan apa imbalan yang diperoleh. Disamping itu komunikator juga harus dapat diterima secara sosial, dan memiliki fisik yang menarik. Aspek-aspek tersebut telah dipenuhi oleh komunikator JSR sehingga banyak orang yang ingin mengetahui dan menjalankan pola hidup sehat JSR sebagaimana yang terlihat dari jawaban followers akun instagram di kuesioner yang dibagikan.

Dalam proses komunikasi, segala aspek dari diri komunikator dapat mempengaruhi hasil dari proses komunikasi, termasuk gaya berpakaian (Widianto \& Pratiwi, 2015). Gaya berpakaian memiliki pengaruh yang cukup signifikan terhadap 
persepsi orang lain mengingat gaya pakaian dapat membuat individu tampil lebih menarik. Dengan penampilan yang menarik, seorang komunikator dapat lebih mudah membujuk orang untuk berubah pikiran. Dr. Zaidul Akbar dipersepsikan oleh responden sebagai komunikator dengan gaya berpakaian yang enak dilihat, santai dan modern.

Gaya pakaian yang dipilihnya tidak hanya didominasi oleh pakaian dokter atau seorang juru dakwah saja melainkan bervariasi sesuai dengan konteks dan situasi tanpa menghilangkan identitasnya sebagai seorang juru dakwah, yaitu peci. Pemilihan pakaian tersebut diakui responden sebagai hal yang unik dan sedikit mencuri perhatian. Dalam konteks ini, dapat dikatakan bahwa ketertarikan responden untuk mengikuti pola JSR bukan karena gaya berpakaian komunikatornya.

Hal ini sesuai dengan pemaparan Perloff (2017) bahwa gaya berpakaian bukan faktor utama dalam perubahan perilaku, namun hanya sebagai pemicu pinggiran (peripheral route) untuk mendengarkan pesan yang disampaikan. Alasannya adalah khalayak lebih suka memperhatikan komunikator yang menarik sehingga pesan yang disampaikan lebih berpotensi untuk diingat dan mau mendengarkan apa yang disarankan oleh sang komunikator. Uraian tersebut semakin meneguhkan bahwa komunikator yang memiliki daya tarik fisik lebih persuasif dibandingkan dengan yang kurang daya tarik fisiknya.

Berkaitan dengan daya tarik komunikator, Rakhmat (2019) menyebutkan bahwa daya tarik bukan hanya fisik, melainkan psikologis juga. Daya tarik psikologis diukur melalui kesamaan agama, kesamaan ideologi, keakraban, kesukaan pada figur dan kesukaan pada pekerjaan. Responden penelitian mengakui bahwa ketertarikannya untuk menjadifollowers@zaidulakbar adalah karena adanya kesamaan agama antara dirinya dan komunikator, yaitu sesama muslim. Schlundt et al., (2008) terkait temuan tersebut menyatakan bahwa orang cenderung untuk bergabung dengan komunitas yang memiliki agama yang sama.

Ahmad \& Harrison (2007) menuliskan bahwa agama telah diidentifikasi sebagai komponen normatif yang potensial dalam kerangka pengetahuan, sikap, dan praktek terkait perilaku kesehatan. Hal ini sesuai dengan penelitian sebelumnya yang menemukan bahwa pendekatan agama dapat digunakan dalam upaya-upaya pencegahan mengingat sebagian besar penyakit terjadi karena perilaku individu (Koening et al., 2001). Oleh karenanya, temuan penelitian yang menunjukkan bahwa kesamaan agama merupakan alasan responden untuk mau menerapkan pola hidup sehat JSR bukanlah sesuatu yang baru.

Sementara itu beberapa responden menuturkan keinginannya untuk melakukan pola hidup sehat JSR adalah karena adanya kesamaan ideologi, sikap dan pendapat bahwa hidup sehat itu penting. Terkait kesamaan, Rakhmat (2019) menerangkan apabila komunikator dan khalayak memiliki kesamaan, maka komunikasi akan lebih efektif karena individu pada dasarnya suka berkomunikasi dengan individu yang memiliki kesamaan. Ketika khalayak tertarik pada komunikator yang memiliki kesamaan, maka 
khalayak juga cenderung lebih mudah menerima gagasan yang disampaikannya. Pada akhirnya, kesamaan dapat mempermudah terjadinya perubahan pendapat.

Kesamaan menurut Sitompul (2018) dapat menimbulkan keakraban. Dalam hal ini keakraban yang dimaksud adalah seringnya melihat atau mendengar dr. Zaidul Akbar di berbagai channel baik di akun instagram, youtube maupun di media lain. Daya tarik psikologis lain yang membuat khalayak mau mendengarkan gagasan komunikator adalah faktor kesukaan terhadap figur komunikatornya. Dr. Zaidul Akbar misalnya dianggap sebagai komunikator yang ramah dan humoris sehingga apa yang disampaikan mudah diterima. Disamping itu, responden juga tertarik dengan pesan dokter JSR karena dianggap sebagai dokter dan pendakwah yang hebat dan mampu meyakinkan bahwa pola hidup sehat akan membuat badan sehat dan memudahkan untuk beribadah.

Sebagaimana yang dijelaskan oleh Silk et al., (2011), kekaguman khalayak terhadap komunikator dapat menghasilkan pengaruh yang besar dalam merekomendasikan atau mendemonstrasikan sebuah argumen. Dengan demikian dapat diketahui bahwa eratnya kaitan daya tarik dr. Zaidul Akbar dengan sikap followers yang mengikuti akun instagram @zaidulakbar dan menerapkan pola hidup sehat JSR disebabkan oleh penampilan fisik, kesukaan, persamaan ideologi, motivasi, pengalaman terkait kesehatan maupun elemen lain dari daya tarik fisik dan psikologis.

Daya tarik diakui sebagai salah satu dimensi yang secara signifikan dapat menimbulkan perilaku positif terhadap sebuah produk sehingga dapat membangun kredibiltas komunikator. Namun demikian, daya tarik bukanlah satu-satunya dimensi dalam kredibilitas komunikator. Sebagaimana yang dijabarkan oleh Rakhmat (2019) bahwa kredibilitas adalah seperangkat persepsi khalayak tentang sifat-sifat komunikator yang didalamnya mencakup komponen keahlian, keterpercayaan dan daya tarik fisik. Dengan demikian, kredibilitas komunikator merupakan aspek eksternal yang dapat dibangun dengan menyesuaikan pada topik yang dibahas, serta situasinya.

Berdasarkan tabel olah data penelitian diketahui bahwa terdapat hubungan yang tinggi antara kredibilitas komunikator dr. Zaidul Akbar dengan sikap followers akun instagram@zaidulakbar terhadap pola hidup sehat JSR yang terlihat dari nilai koefisien korelasi mencapai nilai 0,834. Hasil penelitian memperkuat penelitian-penelitian sebelumnya bahwa kredibilitas memiliki hubungan yang signifikan dengan sikap khalayak dimana komunikator yang memiliki kredibilitas tinggi dapat lebih mudah mempersuasi khalayak dibanding komunikator yang kredibilitasnya rendah (Major \& Coleman, 2012; Major \& Coleman, 2012; Sundary \& Fahmi, 2018).

\section{Simpulan}

Pola hidup sehat JSR yang digagas oleh dr. Zaidul Akbar sangat fenomenal dan viral karena banyak diperbincangkan di media sosial. Selain hangat diperbincangkan di media sosial, kajian dan seminar JSR banyak pula diadakan oleh lembaga dakwah maupun non dakwah dengan mengundang langsung penggagasnya sebagai pembicara. 
Banyaknya followers yang mengikuti akun instagram (IG) dr. Zaidul Akbar menunjukkan bahwa komunikasi dakwah kesehatan ini menarik perhatian dan diikuti banyak orang. Masyarakat mengakui bahwa mereka ingin mengetahui serta menerapkannya dalam kehidupan sehari-hari baik untuk mengobati penyakit, untuk gaya hidup sehat atau untuk mengikuti sunnah. Fakta tersebut menunjukkan bahwa dr. Zaidul Akbar memiliki daya persuasif yang kuat sehingga mampu mengajak masyarakat untuk memiliki hidup yang lebih sehat.

Sebagai komunikator dakwah kesehatan, dr. Zaidul akbar dianggap memiliki kredibilitas komunikator yang tinggi terhadap pola hidup sehat JSR. Artinya, dr. Zaidul Akbar lebih mudah mempersuasi khalayak terkait pola hidup sehat. Hal ini disebabkan karena dr. Zaidul Akbar dianggap memiliki keahlian berupa pengetahuan yang komprehensif tentang kesehatan dan pola hidup sehat JSR dan dapat menyampaikannya dengan jelas dan mudah dipahami. Selain itu dr. Zaidul Akbar memiliki kualifikasi pendidikan dan telah berpengalaman tidak hanya sebagai dokter secara umum tetapi juga dokter yang telah menggunakan dan mengajarkan produk JSR. Hasil penelitian juga menunjukkan bahwa dr. Zaidul akbar memperoleh keterpercayaan dari khalayak karena objektifitas, kejujuran, integritas dan rasa tanggung jawab sosial dr. zaidul akbar terkait dakwah kesehatan berupa pola hidup sehat JSR. Disamping itu ditemukan bahwa daya tarik fisik maupun psikologis komunikator JSR berkontribusi terhadap sikap followers akun instagramnya mengenai pola hidup sehat tersebut.

Dengan demikian dapat disimpulkan bahwa kredibilitas komunikator memiliki hubungan yang erat dengan sikap followers akun Instagram@zaidulakbar mengenai pola hidup sehat JSR. Penelitian ini juga meneguhkan penelitian sebelumnya bahwa konsep komunikator yang memiliki kredibilitas tinggi lebih menarik, dipercaya, dan dapat membujuk khalayak daripada komunikator dengan kredibilitas rendah, juga berlaku di bidang dakwah kesehatan. Adapun saran untuk penelitian selanjutnya adalah dengan melakukan penelitian tentang pola hidup sehat JSR dengan pendekatan kualitatif supaya mendapatkan penjelasan ilmiah yang lebih mendalam, misalnya mengenai motif menerapkan pola hidup sehat JSR.

\section{Referensi}

Abednego, A., \& Triarini, D. (2016). Pengaruh Body Attractiveness Laki-laki Terhadap Pemilihan Pasangan Pada Perempuan Dewasa Muda di Daerah Rural dan Urban [Universitas Indonesia]. http://www.lib.ui.ac.id/naskahringkas/2016-06/S56534Andreas Abednego Kristariyanto

Ahmad, M. Kh., \& Harrison, J. (2007). Untapped potential: Cultural sensitivity-Islamic persuasive communication in health promotion programs. Global Communication and Development Conference, 16-21 October 2007, October, 16-21.

Alsakinah, N. (2018). Kredibilitas Komunikator Ustadz pada Kalangan Jamaah. Prosiding Manajemen Komunikasi, 642-647. 
Andreassen, H.K., Bujnowska-Fedak, M.M., Chronaki, C. E. et al. (2007). European Citizens' Use of E-Health Services: A Study of Seven Countries. BMC Public Health, 7(53). https://doi.org/doi.org/10.1186/1471-2458-7-53

Arafat, M. Y. (2018). Pengaruh Citra Tubuh Ideal Dan Daya Tarik Fisik Terhadap Kemampuan Interpersonal Pada Pria yang Berolahraga di Pusat Kebugaran atau Fitness Center di Samarinda Seberang. PSIKOBORNEO, 6(4), 748-762.

Ashfiah, A. N. (2019). Pengaruh Kredibilitas Ustadz Abdul Somad Terhadap Keputusan Jama'ah Untuk Mengikuti Kegiatan Dakwahnya Di Pekanbaru. JOM FISIP, 6(2), $1-10$.

Assupina, M., Misnaniarti, \& Rahmiwati, A. (2013). Analisis Implementasi Program Pengelolaan Penyakit Kronis (Prolanis) Pada Dokter Keluarga PT Askes Di Kota Palembang Tahun 2013. Jurnal Ilmu Kesehatan Masyarakat, 4 (03)(November), 254-261.

Azwar, S. (2010). Sikap Manusia Teori dan Pengukurannya. Yogyakarta: Pustaka Pelajar.

Braunsberger, K., \& Munch, J. M. (1998). Source Expertise Versus Experience Effects In Hospital Advertising. JOURNAL OF SERVICES MARKETING, 12(1), 23-38.

BS. Ma'arif, Parihat., Yusuf, Umar., \& S. (2019). Persuasive Da' wah Activities and the Socio- Demographic Factor. Advances in Social Science, Education and Humanities Research, 307(Sores 2018), 1-6.

Cass, M. (2013). The New Adulthood. https://d3bzyjrsc42331.cloudfront.net/djangosummernote/2017-10-30/a3327efd-90f6-4a39-8bc6-1a4d837ba053.pdf

Clark, J. K., Wegener, D. T., Habashi, M. M., Evans, A. T., \& Evans, A. T. (2012). Personality and Social Psychology Bulletin or Support on Message Scrutiny. Personality and Social Psychology Bulletin, 38(1), 90-100. https://doi.org/10.1177/0146167211420733

Conner, T., Brookie, K., Carr, A., Mainvil, L., \& Vissers, M. (2017). Let Them Eat Fruit! The Effect of Fruit And Vegetable Consumption on Psychological WellBeing in Young Adults : A Randomized Controlled Trial. PLoS ONE, 12(2), 1-19. https://doi.org/10.1371/journal.pone.0171206

Davenport, T. H., \& Prusak, L. (2000). Working Knowledge: How Organizations Manage What They Know. Boston: Harvard Business Press.

Davis, S. L., Rives, L. M., \& Maya, S. R. De. (2017). Introducing Personal Social Responsibility as A Key Element to Upgrade CSR. Spanish Journal of Marketing ESIC, 21, 146-163. https://doi.org/10.1016/j.sjme.2017.04.001

Doyle, B. T. (2004). OBJECTIVE VS. SUBJECTIVE INFORMATION. www.barbaradoyle.com

E.Ayub, Moh., Muhsin MK., \& Mardjoned, R. (2007). Manajemen Masjid (9th ed.). Jakarta: Gema Insani.

Fitzgibbon, M. L., Kong, A., \& Tussing-Humphreys, L. (2014). Understanding 
Population Health From Multi-Level and Community-Based Models. In K. A. RIEKERT, J. K. OCKENE, \& L. PBERT (Eds.), The HANDBOOK of HEALTH BEHAVIOR CHANGE (pp. 28-46). New York: Springer Publishing Company.

Gordon, R. ., Crosnoe, R., \& Wang, X. (2013). Physical Attractiveness and The Accumulation of Social and Human Capital In Adolescence and Young Adulthood: Assets and Distractions. Monographs of the Society for Research in Child Development, 78(6), 1-137. https://doi.org/10.1002/mono.12060

Hariyanto. (2018). Relasi Kredibilitas Da'i Dan Kebutuhan Mad'u Dalam Mencapai Tujuan Dakwah. Tasâmuh, 16(2), 61-82.

Hidayat, A. S. (2013). Membangun Dimensi Baru Dakwah Islam: Dari Dakwah Tekstual menuju Dakwah Kontekstual. Jurnal Risalah, 24(2), 1-15.

Husin, A. F. (2014). Islam dan kesehatan. Islamuna, 1 (2), 194-209.

Ilham, R., Mohammad, S., \& Syukriani Yusuf, M. N. (2019). Hubungan Tingkat Pengetahuan Dengan Sikap Perawat Tentang Perawatan Paliatif. Jambura Nursing Journal, 1(2), 96-102.

James T. Scarnati. (2013). Beyond Technical Competence: Honesty and Integrity. Career Development International, 2(1), 24-27.

Kareklas, I., Muehling, D. D., \& Weber, T. J. (2015). Reexamining Health Messages in the Digital Age: A Fresh Look at Source Credibility Effects. Journal of Advertising, 44(2), 88-104. https://doi.org/10.1080/00913367.2015.1018461

Koening, H. G., McCullough, M. E., \& Larson, D. B. (2001). Handbook of Religion and Health. New York: Oxford University Press.

Kriyantono, R. (2012). Teknik Praktis Riset Komunikasi. Jakarta: Kencana Prenada Media.

Lamm, Alexa J., Owens, Courtney T., Telg, Ricky W., \& Lamm, K. W. (2016). Influence of Source Credibility on Agricultural Water Use Communication. Journal of Applied Communications, 100(3), 121-132.

Laranjo, L. (2016). Social Media and Health Behavior Change. In S. Syed-Abdul, E. Gabarron, \& A. Y. S. Lau (Eds.), Participatory Health Through Social Media (pp. 83-111). Academic Press.

Lou, C., \& Yuan, S. (2018). Influencer Marketing: How Message Value and Credibility Affect Consumer Trust of Branded Content on Social Media. Journal of Interactive Advertising. https://doi.org/10.1080/15252019.2018.1533501

Major, L. H., \& Coleman, R. (2012). Source Credibility and Evidence Format: Examining the Effectiveness of HIV/AIDS Messages for Young African Americans. Journal of Health Communication: International Perspectives, 17(5), 515-531. https://doi.org/10.1080/10810730.2011.635771

Mubarak, W. (2011). Promosi Kesehatan Untuk Kebidanan. Jakarta: Salemba Medika. Mulizar. (2017). In Memoriam Konsep Dakwah Dan Pemikiran Pakar Hadis; Prof. Dr. KH. Ali Mustafa Yaqub, MA. Jurnal Al-Hikmah, IX(14), 43-61. 
Ohanian, R. (1991). The Impact of Celebrity Spokespersons' Perceived Image on Consumers' Intention to Purchase. Journal of Advertising Research, 31(1), 46-54.

Păceşilă, M. (2018). The Individual Social Responsibility: Insights From A Literature Review. MANAGEMENT RESEARCH AND PRACTICE, 10(1), 17-26.

Pangil, F., \& Nasurddin, A. M. (2013). Knowledge and the Importance of Knowledge Sharing in Organizations. Conference on Business Management Research 2013. http://repo.uum.edu.my/16360/1/15.pdf

Parvanta, C. F., \& Bass, S. B. (2020). Health Communication: Strategies and Skills for a New Era. Burlington MA: Jones \& Bartlett Learning.

Perloff, R. M. (2017). The Dynamics of Persuasion (6th ed.). New York: Routledge.

Prasetyo, A. (2019). The Persuasive Da 'Wah Communication of KH Asyhari Marzuqi And Its Implications in Modern Life. INFORMASI, 49(1), 11-24.

Prawira W, R. Y., Mulyana, S., \& Wirakusumah, T. K. (2012). Hubungan Karakteristik Brand Ambassador Honda Spacy Helm-In dengan Tahapan Keputusan Pembelian Konsumen. EJurnal Mahasiswa Universitas Padjadjaran, 1(1), 1-14.

Rahmadiana, M. (2012). Komunikasi Kesehatan: Sebuah Tinjauan. Jurnal Psikogenesis, $1(1), 88-94$.

Rahmah, M. N. (2013). Kredibilitas Juru Dakwah sebagai Komunikator. Alhadharah Jurnal Ilmu Dakwah, 12(24), 1-13.

Rakhmat, Jalaluddin., \& Ibrahim, I. S. (2017). Metode Penelitian Komunikasi. Bandung: Simbiosa Rekatama Media.

Rakhmat, J. (2019). Psikologi Komunikasi. Bandung: Simbiosa Rekatama Media.

Riswandi. (2013). Psikologi Komunikasi. Yogyakarta: Graha Ilmu.

Rooney, C., Mckinley, M. C., \& Woodside, J. V. (2013). The potential role of fruit and vegetables in aspects of psychological well-being: a review of the literature and future directions Proceedings of the Nutrition Society. Proceedings of the Nutrition Society, 72, 420-432. https://doi.org/10.1017/S0029665113003388

Schindler, S., Reinhard, M., Grünewald, F., \& Messner, M. (2017). 'I Want To Persuade You!' - Investigating The Effectiveness of Explicit Persuasion Concerning Attributes of The Communicator and The Marketing Campaign. Social Influence, 1-13. https://doi.org/10.1080/15534510.2017.1378125

Schlundt, D. G., Franklin, M. D., Patel, K., McClellan, L., Larson, C., Niebler, S., \& Hargreaves, M. (2008). Religious Affiliation, Health Behaviors and Outcomes. American Journal of Health Behavior, 32(6), 714-724. https://doi.org/10.5555/ajhb.2008.32.6.714

Shell, R., \& Moussa, M. (2007). The Art of Woo: Using Strategic Persuasion to Sell Your Ideas. New York: Penguin Group.

Silk, K. J., Atkin, C. K., \& Salmon, C. T. (2011). Developing Effective Media Campaigns For Health Promotion. In T. L. Thompson, R. Parrott, \& J. F. Nussbaum (Eds.), The Routledge Handbook of Health Communication. New York: 
Taylor \& Francis.

Sitompul, S. (2018). Hubungan Antara Kesamaan (Similarity) Dengan Pembentuk Persahabatan Pada Remaja Di Kelurahan VII Tarutung [Universitas Medan Area]. http://repository.uma.ac.id/bitstream/123456789/9845/1/Syarah Sitompul fulltext.pdf

Sugiyono. (2010). Statistika Untuk Penelitian. Bandung: Alfabeta.

Sundary, D. A., \& Fahmi, M. H. (2018). Hubungan antara Komunikasi Dakwah Ustadz Evie Effendie dengan Pengetahuan Keagamaan Sisterfillah Bandung. Prosiding Hubungan Masyarakat, 719-722.

Telg, Ricky., Irani, T., Monaghan, P., Chiarelli, C., Scicchitano, M., \& Johns, T. (2012). Preferred Information Channels and Source Trustworthiness: Assessing Communication Methods Used in Florida's Battle Against Citrus Greening Preferred Information Channels and Source Trustworthiness: Assessing Communication Methods Used in Florida' s. Journal of Applied Communications, 96(1), 42-53.

Venus, A. (2012). Manajemen Kampanye: Panduan Teoretis dan Praktis. Bandung: Simbiosa Rekatama Media.

Wahl, D. ., Villinger, K., König, L. ., \& Al, E. (2017). Choices Are Happy Food Choices: Evidence From A Real Life Sample Using Smartphone Based Assessments. Sci Rep, 7. https://doi.org/10.1038/s41598-017-17262-9

Waters, E. A., McQueen, A., \& Cameron, L. D. (2014). Perceived Risk and Health Risk Communication. In H. E. Hamilton \& W. S. Chou (Eds.), The Routledge Handbook of Language and (pp. 47-60). New York: Routledge.

Wawan, A., \& Dewi, M. (2010). Teori dan Pengukuran Pengetahuan Sikap dan Perilaku Manusia : Dilengkapi Contoh Kuesioner. Yogyakarta: Nuha Medika.

Westerman, D., Spence, P. R., \& Van Der Heide, B. (2014). Social Media as Information Source : Recency of Updates and Credibility of Information *. Journal of Computer-Mediated Communication, 19, 171-183. https://doi.org/10.1111/jcc4.12041

Widianto, F. R., \& Pratiwi, F. D. (2015). Audience Adaptation Dalam Gaya ( Studi Deskriptif Kualitatif Trend Jilboobs Pada Mahasiswi Yogyakarta ). Jurnal Komunikasi PROFETIK, 8(2), 81-93.

Yasin, B., \& Ozen, H. (2011). Gender Differences in The Use of Internet for Health Information Search. EGE ACADEMIC REVIEW, 11(2), 229-240. https://doi.org/10.21121/eab.2011219567

Ybarra, M. L., \& Suman, M. (2006). Help seeking behavior and the Internet: A national survey. International Journal of Medical Informatics, 75, 29-41. https://doi.org/10.1016/j.ijmedinf.2005.07.029 